\title{
EFFECTS OF THE SOFT ROCK PRE-CONSOLIDATION ON TIME-DEPENDENT DEFORMATIONS AROUND THE TUNNEL EXCAVATION
}

\author{
Zvonko Tomanovic
}

Original scientific paper Time-dependent deformations in soft rocks represent an important part of total deformations which occur after excavation of the tunnel opening. In the light of this, comprehensive laboratory uniaxial creep tests were performed on marl rock monolits. The testing used marl as a chosen representative rock samples of the group of soft rocks which exhibits creep behaviour. Analysis of test records of total and time-dependent deformations in initially nonpreconsolidated and pre-consolidated samples indicates differences in the magnitude of total deformation and the shape of recorded creep curve. A limited experimental evidence is argument in favor of the thesis that the primary creep is actually a delayed elastic deformation that is not significantly affected by the pre-consolidation stress history. Phenomenology of behavior identified in the tested marl samples can be associated with the records of the convergence measurements on a tunnel contour being excavated in soft rocks.

Keywords: convergence; creep; primary creep; pre-consolidation; secondary creep

Efekti prekonsolidacije meke stijene na vremenski ovisne deformacije oko tunelskog iskopa

Izvorni znanstveni članak Vremenksi ovisne deformacije u mekoj stijeni prestavljaju važan dio ukupnih deformacija koje se javljaju oko tunelskog otvora. U svijetlu ovoga, izvedena su široka laboratorijska testiranja na monolitnim jednoaksijalnim uzorcima lapora. Testirani lapor je izabran kao reprezentativna stijena iz grupe mekih stijena koje pokazuju značajnu osobinu puzanje. Analiza podataka ukupnih i vremenski zavisnih deformacija inicijalno neprekosolidiranih prekonsolidiranih uzoraka ukazuje na razlike u veličini ukupne deformacije i obliku krivulje puzanja. Ograničena eksperimentalna evidencija ide u prilog tezi da je primarno puzanje zapravo zakašnjela elastičnost na čiju ukupnu vrijednost nema znatnog uticaja prekonsolidacija materijala. Fenomenologija ponašanja uočena na ispitivanim uzorcima laporca može se povezati sa oblikom krivulje konvergencije tunelske konture nakon iskopa u mekim stijenama.

Ključne riječi: konvergencija; puzanje; primarno puzanje; prekonsolidacija; sekundarno puzanje

\section{Introduction}

Modern support systems for tunnels are based on application of flexible support and mobilization of bearing capacity of rock around the tunnel excavation, where rock mass forms part of the support system. Software for numerical modelling of such complex geotechnical system is performed in order to define the proper support system that will ensure stability of the tunnel opening. Unfortunately, accuracy and reliability of these calculations depends on large number of parameters, hence the adjustments of the designed support system are required in the course of the tunnel construction. The need for adjustments of the designed tunnel support structure is mostly based on measurements of the excavation contour movements, i.e. convergence of radial displacement over time, which indicates whether the balance is achieved between the rock mass pressure and response of the support systems $[1,2]$.

The increment of radial deformations of the tunnel opening contour over time is closely linked to the timedependent characteristics of the support system, however primarily to the creep in the rock mass in which the change in the strain-stress state occurred after excavation of the tunnel opening. The presence of creep behaviour is particularly noticed for clay and soft rock. Relatively soon after the wider application of the tunnel flexible support (shotcrete, reinforcing mesh and anchors, NATM) a significant difference is noticed between theoretical solutions and movements recorded in the constructed tunnels. After comprehensive investigations of the rock creep and behaviour of the rock around the tunnel opening, complex rheological models are formed which provide description of the time-dependent behaviour of the rock around the tunnel opening $[3 \div 11]$, etc.

In the past, the issue of deformations, particularly the time-dependent deformations, used to be solved by empirical formulas, which in case of the tunnels offered economically and technically viable results for a certain period. No earlier than some 10 years ago, some software packages provided an option for computation of the timedependent deformations, as a result of the constitutive models which included also the time-dependent components of deformations and numerical methods as well as due to the enhanced capacity and speed of computers. Purposefulness of the research on the problem concerned arises from the necessity to provide numerical modelling for the contemporary process of excavation and construction of the support system, based on the rock mass-substructure interaction under the time-dependent conditions, as well as to enable understanding of the stress-strain state during excavation works and in the course of operation.

However, regardless of the complexity of the geotechnical and rheological models applied in calculation of the tunnel stability and dimensioning of support system, corrective measures are commonly taken during the tunnel construction. These corrective measures are mostly based on: the extent of the radial displacement, the time dependent convergence of radial displacement of the tunnel opening contour and diagram shape of recorded convergence $[12 \div 16]$.

\section{Laboratory tests}

Research on rheological behaviour of the rock mass is characterized by a distinctive problem in defining the 
exact material constants and parameters used in a rheological model, relating to the description of the rock matrix behaviour and impact of discontinuities, being a consequence of a specific composition of the rock material (discrete mineralogical composition, bedding planes and other discontinuities, etc.). Contemporary experimental researches usually include specific tests to determine particular material constants and parameters which are required to define a rheological model of the rock matrix or discontinuity. In research on timedependent rock deformation and formulation of a rheological model of the rock mass behaviour based on time-dependent deformations, a creep test holds a special place. By definition, the creep test is characterized by a constant load, in other words a continuous stress applied during the testing and measuring of the deformation increments against time.

To obtain an adequate numerical model of the stressstrain state of the rock around the tunnel excavation, it is necessary to understand the phenomenon of rock behaviour under conditions of the time-dependent deformations. Additionally, it is equally important and is one of the objectives of the experimental research, to provide proper material parameters of the rock matrix, through determining material constants and parameters. Tested monoliths of marl, selected as a representative rock from the group of soft rock, in its chemical contents contains $\mathrm{CaCO} 3$ in limits $48,10 \div 48,30 \%$, while the contents of insoluble rest (clayey+quartzite) is in limits $51,03 \div 51,87 \%$. Regarding the mineralogical contents, calcite $(46 \div 48 \%)$ and quartz $(12 \div 13 \%)$ represent dominant mineral phases, while in clayey phase there are illite and smektite, montmorillonite, kaolinite, glauconite, transformed feldspar and mica. Moisture of the sample was from $8 \div 11 \%$, and uniaxial strength of the material was about $\sigma_{\mathrm{c}}=8,8 \mathrm{MPa}$, [8].

Main characteristic of conventional laboratory test and in-situ test methods is to work on simple geometrical shapes and more or less simple stress states. Commonly, material parameters obtained from such tests are used in mathematical models of rheological behaviour which describe the stress-dependent phenomena in general terms, therefore also applicable in the field of soil and rock mechanics.

The most commonly used and the simplest creep test is performed on cylindrical or prismatic specimens at an uniaxial stress state. Formulation of the rheological model for the purpose of performed research is based on the creep test data obtained on the uniaxial prismatic specimens of marls with dimensions $15 \times 15 \times 40 \mathrm{~cm}$, Fig. 1 .

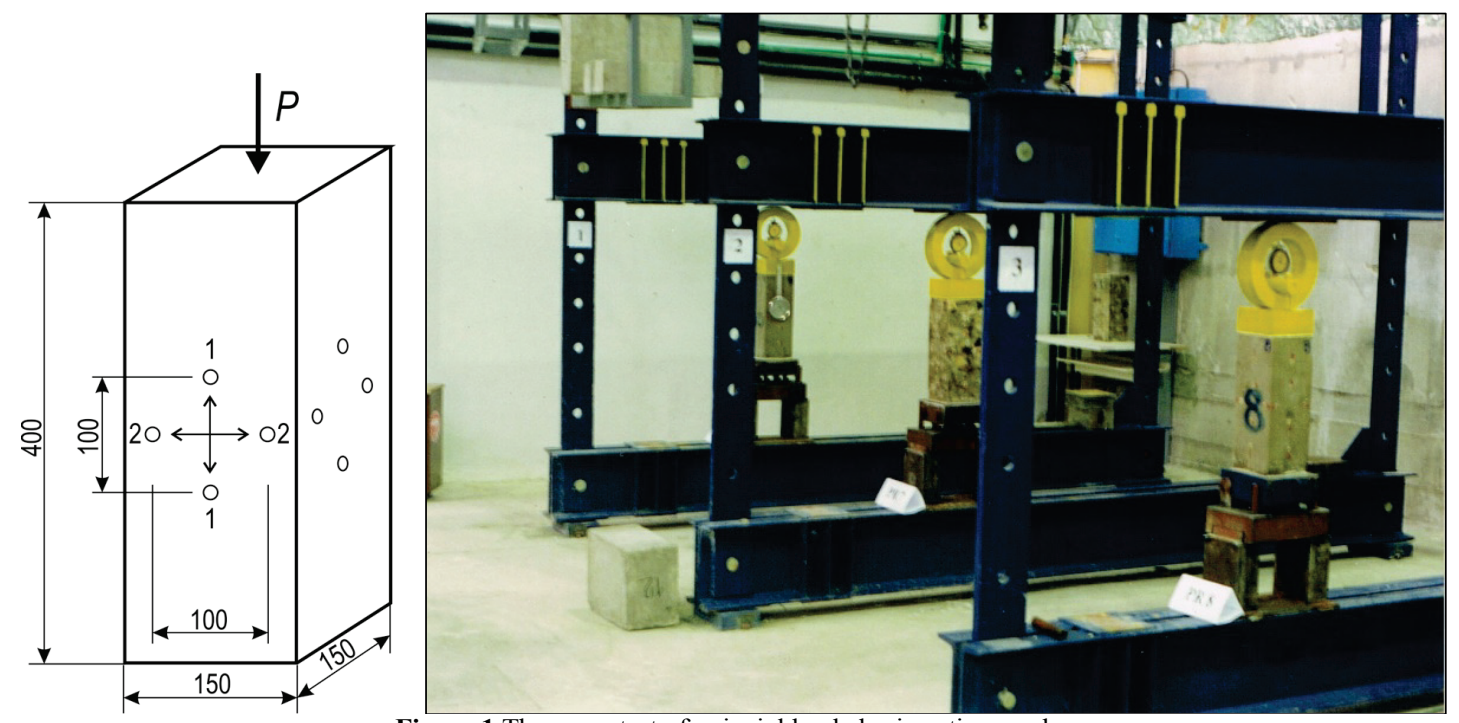

Figure 1 The creep test of uniaxial loaded prismatic samples

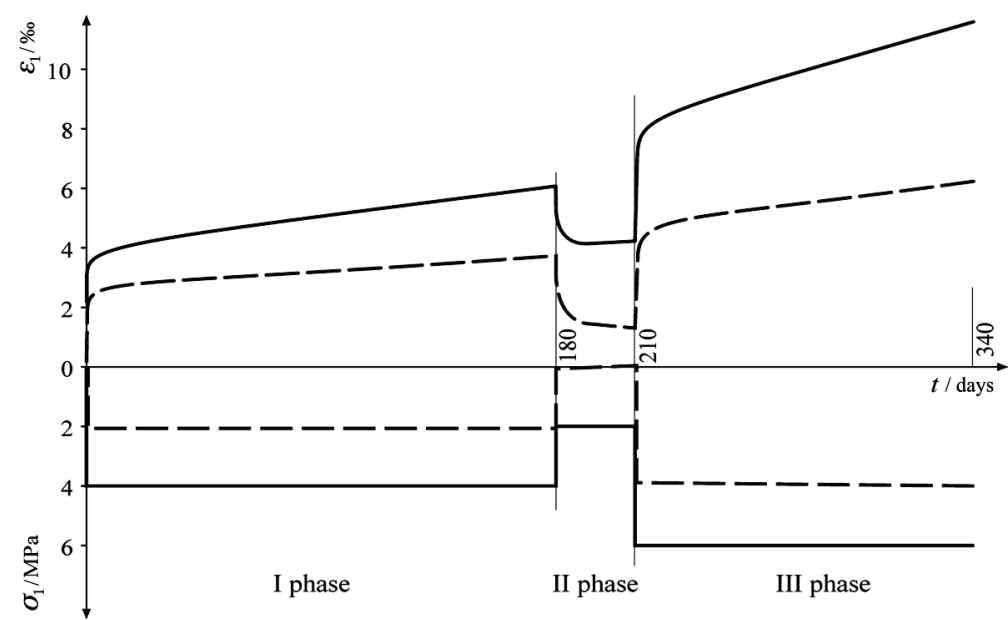

Figure 2 Diagram of phases of the creep test of uniaxial loaded prismatic samples 
The test procedure carried out on samples is presented in deformation-time and stress-time curves, Fig. 2. The test was performed in three phases: loading, unloading and reloading to a higher level of stress with maintaining its value constant during the final loading state. Loading of the samples was conducted in increments of $25 \%$ of defined level of constant stress in the creep test, for every group of samples.

Average values of deformation measurements on three unconsolidated prismatic specimens out of each group of specimens that were subjected to different loading, at axial compression load of 2,0 $\mathrm{MPa}$ and 4,0 $\mathrm{MPa}$ are illustrated in Fig. 3 [8].

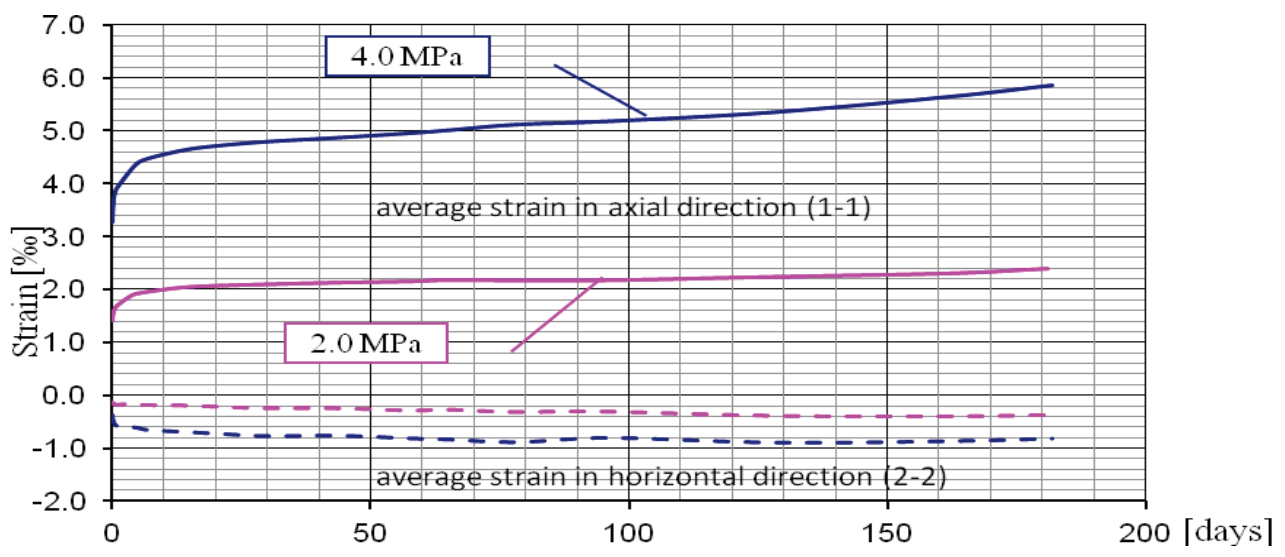

Figure3 Diagram of phases of the creep test of uniaxial loaded prismatic samples

\section{Measurement results}

3.1 Effects of pre-consolidation in case of the short-term loading

The time-dependent deformation behaviour of materials largely depends on the stress-strain pre-history. Therefore, an actual deformation is in addition to the current stress state also influenced by the level and duration of the load applied in the past. Test results of the prismatic uniaxial specimens in the third phase of the test, where the specimens once unloaded were reloaded to the higher stress level, indicate the effects of the stress history on the actual deformation of the examined marl. During the creep test, a type of consolidation occurs which results in the re-grouping and re-orientation of the rock grains, and eventually in certain water escape. These effects result in the material hardening compared to the first loading, meaning deformations at lesser extent are observed at reloading.
Fig. 4 illustrates a comparative diagram for behaviour of nonconsolidated material at the first loading and after the influence of stress of 2,0 $\mathrm{MPa}$ and 4,0 $\mathrm{MPa}$. The deformation observed at the stress of 4,0 $\mathrm{MPa}$, at reloading, is three times lower than the deformation observed at the first loading on specimens which were earlier subject to a long-term stress loading of 4,0 $\mathrm{MPa}$. Lesser dispersion of results after a long-term creep test is also recorded.

The stress-strain comparative diagram at reloading indicates that in case of the examined marl, there is highly notable effect of pre-consolidation of material at the short-term deformation behaviour. The behaviour of material highly depends on the stress level at which the material was strained during long period. The described influence on the sample behaviour at reloading state has increased concurrently with the increased preconsolidation stress.

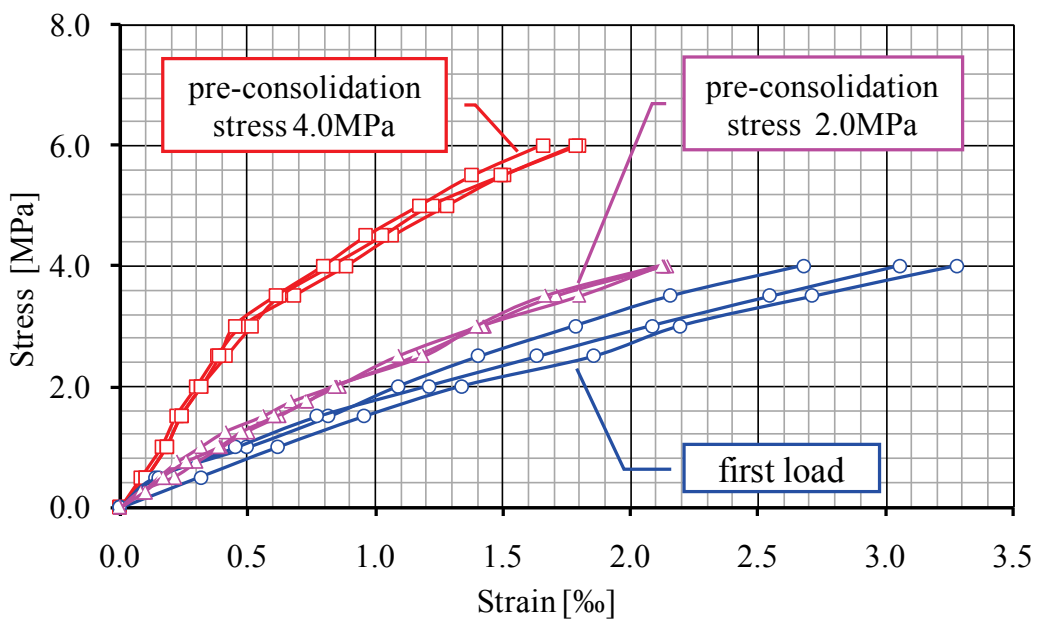

Figure 4 Stress-strain diagram at reloading of prismatic specimens

The stress-strain comparative diagram at reloading indicates that in case of the examined marl, there is highly notable effect of pre-consolidation of material at the short-term deformation behaviour. The behaviour of 
material highly depends on the stress level at which the material was strained during long period (at creep test). The influence on the behaviour of material at reloading increases in line with the increased pre-consolidation stress.

It should be noted that the specimens subjected to the creep test at stress of 2,0 MPa were relaxed of stress to zero 30 days before the reloading, hence the timedeformation of reversible creep was released. On the other hand, the specimens loaded with the stress of 4,0 $\mathrm{MPa}$ at creep test were relaxed to the stress level of 2,0 $\mathrm{MPa} 30$ days before the reloading, while relaxed from the stress of 2,0 $\mathrm{MPa}$ to zero several hours before the reloading. Therefore, in case of the second group of specimens, there was not sufficient time for developing of the total delayed elastic deformation i.e. deformation of reversible creep, which explains significantly lesser extent of total deformation at stress of 4,0 $\mathrm{MPa}$ (specimens with a prestress of 4,0 MPa).

\subsection{Effect of pre-consolidation on the behaviour of material at the repeated creep test}

Fig. 5 illustrates a comparative creep diagram for non-consolidated prismatic specimens at stress of 4,0 $\mathrm{MPa}$ and pre-consolidated prismatic specimens at consolidation stress of 2,0 $\mathrm{MPa}$. The diagram indicates that the initial deformation of the pre-consolidated specimens is lower than the deformation of the specimens without pre-consolidation. Moreover, the creep diagrams for specimens without pre-consolidation and preconsolidated specimens have a different shape in the first 60 days following the loading. After this period, the shape of the creep diagram is almost identical, while the total deformation (initial + creep) is becoming even.

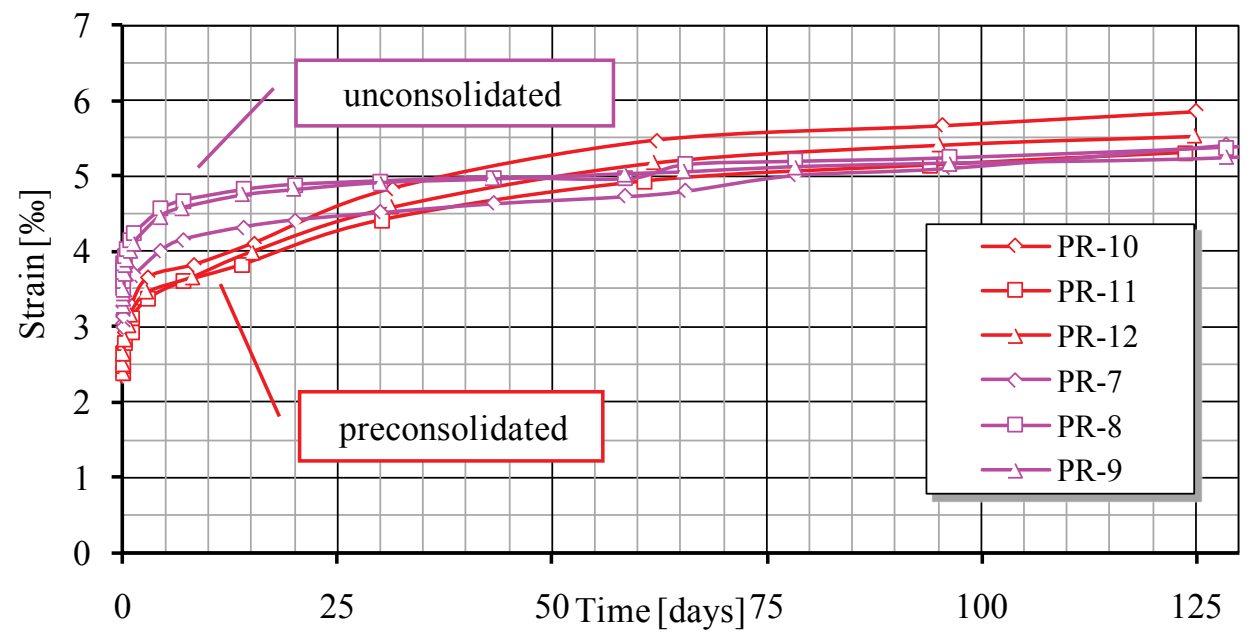

Figure 5 Comparative diagram for total deformation of the creep test at stress of 4,0 MPa for non-consolidated and pre-consolidated specimens respectively ( $\mathrm{PR}$ - mark of prismatic specimen)

Comparative diagram for creep deformation (time dependent component) illustrated in Fig. 6 shows that the creep deformation of pre-consolidated specimens is higher than the deformation of specimens without preconsolidation. The shape of the creep deformation diagram is almost identical in the first five to seven days, with a dominant primary creep observed. Following the period of seven days, the pre-consolidated specimens have higher deformation increment compared to the deformation of specimens without pre-consolidation, in case of which the secondary creep is more influential.

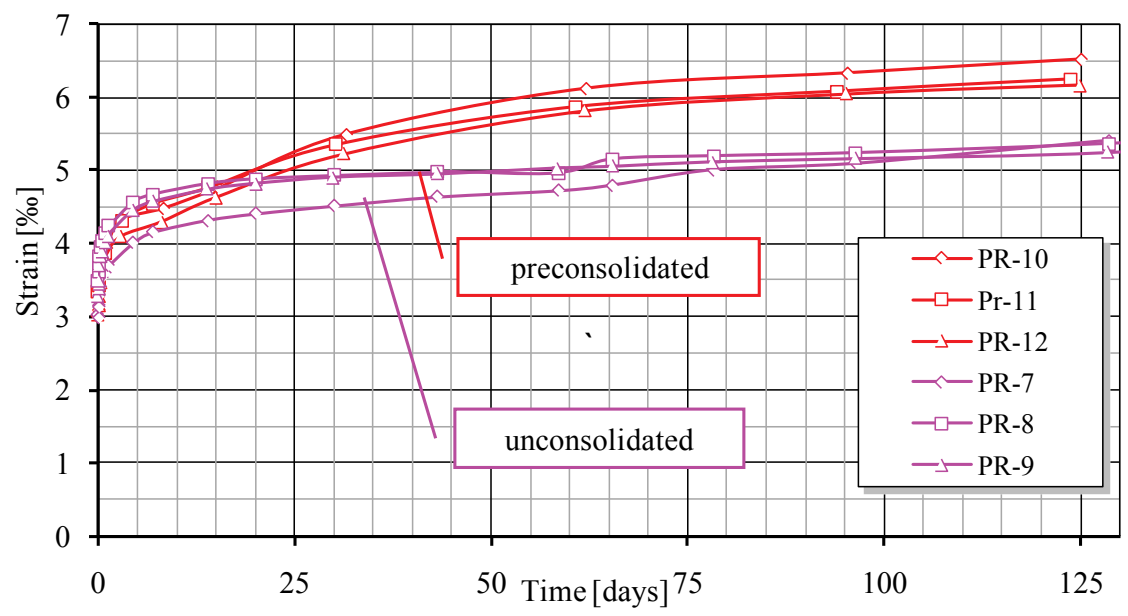

Figure 6 Comparative diagram of the creep deformation at stress of 4,0 MPa for pre-consolidated specimens and specimens without consolidation ( $\mathrm{PR}$ - mark of prismatic specimen) 
Influence of the stress pre-history on the deformation response of the material is evident in case of the shortterm loading, with also evident effects on the course of creep deformation, therefore on the time-dependent deformations. During the creep test, a type of consolidation occurs which results in the re-grouping and re-orientation of the rock grains, and eventually in certain water escape. These effects result in the material hardening compared to the first loading, meaning deformations at lesser extent are observed at reloading.

This limited experimental evidence favours the thesis advocating that the primary creep is actually a delayed elasticity, which sustains no relevant influence from the pre-consolidation of material. On the other hand, the effect of pre-consolidation on the secondary creep is significant in a period of several months after the reloading. Total deformation after a sufficiently long period showed no dependence on pre-consolidation.

\section{Time-dependent deformations around the tunnel opening}

Effects of rock creep around the tunnel opening are most evidently manifested through the increment of radial deformations over time after excavation of the tunnel opening. As for the tunnels whose supporting systems consists of: anchors, reinforcing meshes and shotcrete
(NATM) commonly, radial deformations develop intensively in the first few days, and after that the increment of deformations over time gradually reduces and converges to certain value (if the support system is such to provide balance of forces) Fig. 7. In terms of shape and trend of deformations, this diagram corresponds to the creep of soft rock specimens without pre-consolidation as shown in Fig. 3 and 5.

However, as for the tunnels supported by a flexible supporting (NATM) sometimes the convergence of displacement with low increment of displacement starts in the first few days, which leads to the conclusion that the balance of forces is being reached, and then the creep deformation increment starts again as shown in Fig. 8. In terms of shape, a diagram of increment of radial deformations around the tunnel opening shown in Fig. 8 corresponds to the creep diagram of soft rock specimens without pre - consolidation as shown in Fig. 4 and Fig. 5. In the first four to five days, the slowdown of radial deformations increment is observed (Fig. 8), and after that without any change in the strain-stress state the deformation increment speeds up, as is the case with preconsolidated prismatic specimens in the creep test. The same length sequence of excavation, rock and supporting systems was applied on sites of both profiles used to measure convergence.

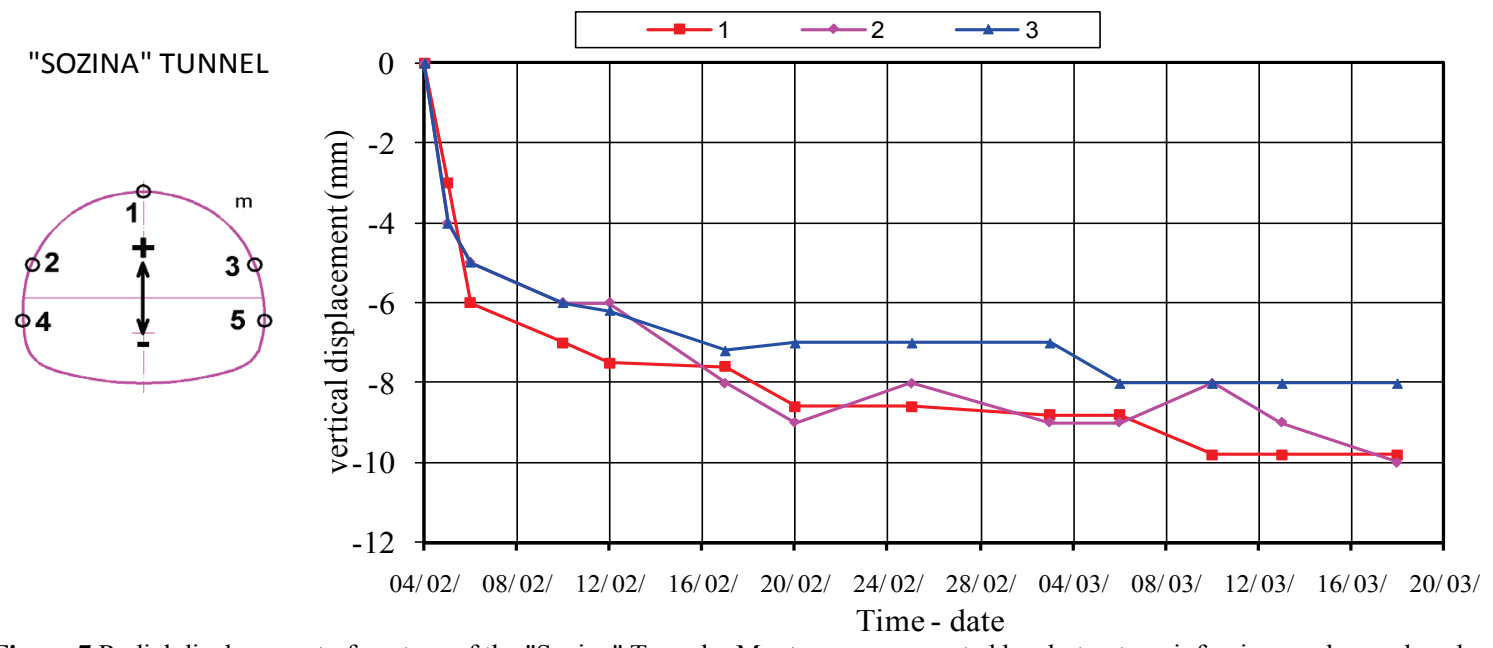

Figure 7 Radial displacement of contour of the "Sozina" Tunnel - Montenegro, supported by shotcrete, reinforcing meshes and anchors

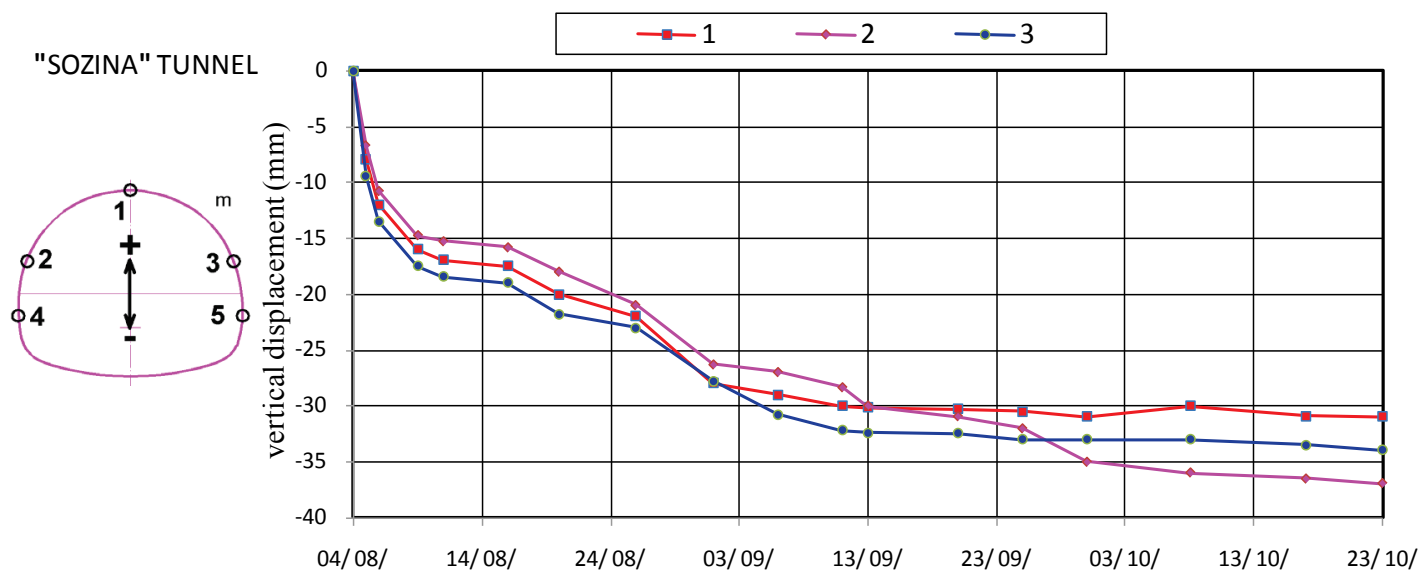

Time - date

Figure 8 Radial displacement of contour of the "Sozina" Tunnel - Montenegro, supported by shotcrete, reinforcing meshes and anchors 


\section{Conclusions}

Response of rock mass after the tunnel excavation is a complex process with far-reaching effects on number of phenomena and parameters. An additional re-loading in the rock mass, induced by the excavation, causes change of the stress state followed by development of deformations. Displacements of the excavation contours occur in line with the excavation process and support construction, but also long after the period of excavation due to the development of the time-dependent components of the rock mass deformation i.e. creep phenomenon.

Pursuant to the previous practice the estimations of the excavation contour displacement are usually based on the experience systematized in empirical classifications and/or by means of empirical formulas. A significant step forward in planning and construction of the underground structures could be achieved if the instantaneous and time-dependent deformations of the underground opening contour that take place after the excavation, were computed already in the design phase, through adequate numerical models.

Pre-consolidation of the examined material also affects the level and the course of the time dependent behaviour of deformations. Therefore, in the first seven to ten days following the reloading, the time-dependent deformations are lesser compared to the ones recorded on specimens without pre-consolidation. After a longer period, the time-dependent deformation of the preconsolidated specimens becomes somewhat higher compared to the normally consolidated specimens. Hence, certain 'pre-consolidation' of marl slows development of the primary creep and delays achievement of the full value of this creep component compared to the normally consolidated specimens for 3 to 5 times longer time period. After a sufficiently long period, total deformation (instantaneous + time-dependent component) of normally consolidated and pre-consolidated specimens becomes nearly even.

This phenomenon can also be related to the measured results of the convergence of the tunnel excavation contour and displacement-time diagrams, where sometimes in the first few days following the tunnel excavation, after an apparent convergence, additional time-dependent deformations occur without stress state being changed. Shape of the tunnel convergence diagrams is quite similar to the creep diagram of the preconsolidated specimens. This suggests that the preconsolidation of rock material can be one of the causes of the accelerated radial displacement of the tunnel excavation contour after apparently established trend of stabilization in the contour displacements in a relatively short period after the excavation.

\section{References}

[1] Rabcewicz, L. V.; Golser, J. The principles of dimensioning the supporting system for the "New Austrian Tunnelling Method". // Water Power. 25, 3(1973), pp. 88-93.

[2] Pacher, F. Ground reaction and lining curves. // Geomechanics and Tunnelling. 3, 4(2010), pp. 402-408. DOI: $10.1002 / g e o t .201000026$
[3] Ladanyi, B. Use of the long-term strength concept in the determination of ground pressure on tunnel linings. // Proc., 3rd Congress of ISRM, National Academy of Sciences, Vol. 2_B_, / Washington, D. C.,1974, pp. 1150-1156.

[4] Sakurai, S. Approximate time-dependent analysis of tunnel support structure considering progress of tunnel face. // Int. J. Numer. Analyt. Meth. Geomech. 2, (1978), pp. 159-175. DOI: 10.1002/nag.1610020205

[5] Time-Dependent Behaviour of Tunnels // Introduction to rock mechanics. / Goodman, R. E. John Wiley \& Sons, 1989, New York, pp. 250-256.

[6] Doring, T.; Kiehl, J. R. Das primare, sekundare und tertiare Kriechen von Steinsalz - Ein dredimensionales rheonomes Stoffesetz. // Geotechnick. 3, (1993), pp. 194-199.

[7] General constitutive equation. // Time effects in Rock Mechanics/Cristescu, N. D. and Hunsche, U., John Willey \& Sons, New York, 1998, pp. 119-179.

[8] Tomanovic, Z. The stress and time dependent behaviour of soft rock. // Gradjevinar. 64, (2012), pp. 993-1007.

[9] Phienwej, N.; Thakur, P. K.; Cording, E. J. Time-dependent response of tunnels considering creep effect. // Int. J. Geomech. 7, 4(2007), pp. 296-306. DOI: 10.1061/(ASCE)1532-3641(2007)7:4(296)

[10] Barla, G. Contributions to the understanding of time dependent behaviour in deep tunnels. // Geomechanics and Tunnelling. 4, 3(2010), pp. 255-264. DOI: 10.1002/geot.201100021

[11] Xu, T.; Tang, C.; Zhao, J. Modelling of Rheological Deformation of Inhomogeneous Rock and Associated Time-Dependent Response of Tunnels. // Int. Jour. of Geomechanics. (2012), pp. 154-159. DOl: 10.1061/(ASCE)GM.1943-5622.0000130

[12] Pan, Y. W.; Dong, J. J. Time-Dependent Tunnel Convergence - I. Formulation of the Model. // J. Rock Mech. and Mining Sci. (1991), pp. 469-475.

[13] Pan, Y. W.; Dong, J. J. Time-Dependent Tunnel Convergence - II. Advance Rate and Tunnel-Support Interaction. // J. Rock Mech. and Mining Sci. (1991), pp. 475-488.

[14] Wong, H.; Subrin, D.; Dias, D. Convergence-confinement analysis of a bolt-supported tunnel using the homogenization method. // Can. Geotech. J. 43, (2006), pp. 462-482. DOI: 10.1139/t06-016

[15] Oreste, P. The Convergence-Confinement Method: Roles and Limits in Modern Geomechanical Tunnel Design. // American Journal of Applied Sciences. 6, 4(2009), pp. 757 771. DOI: 10.3844/ajassp.2009.757.771

[16] Baryshnikovb V. D. Estimating Remaining Life of Underground Tunnel Concrete Lining by Convergence Measurements. // Journal of Mining Science. 48, 3(2012), pp. 440-444. DOI: $10.1134 /$ S1062739148030069

\section{Author's address}

Zvonko Tomanovic, Prof. dr.

Faculty of Civil Engineering, University of Montenegro,

Cetinjski put bb, Podgorica, 81000, Montenegro

E-mail: zvonko@ac.me 